\title{
PET and Macro- and Microautoradiographic Studies Combined with Immunohistochemistry for Monitoring Rat Intestinal Ulceration and Healing Processes
}

\author{
Masanori Yamato ${ }^{1,2}$, Yosky Kataoka ${ }^{1,2}$, Hiroshi Mizuma ${ }^{2}$, Yasuhiro Wada ${ }^{2}$, and Yasuyoshi Watanabe ${ }^{1,2}$ \\ ${ }^{I}$ Department of Physiology, Osaka City University Graduate School of Medicine, Osaka, Japan; and ${ }^{2}$ RIKEN Center for Molecular \\ Imaging Science, Chuo-ku, Kobe, Hyogo, Japan
}

\begin{abstract}
${ }^{18} \mathrm{~F}-\mathrm{FDG}$ PET is used mainly in clinical settings for imaging focal cancer sites, but the usefulness of the modality in imaging gastrointestinal ulcers has not been established. We investigated whether PET can be used for noninvasive monitoring of indomethacin-induced small-intestine ulceration. Methods: Intestinal ulcers were induced in rats by subcutaneous administration of indomethacin. An ${ }^{18} \mathrm{~F}-\mathrm{FDG}$ PET scan was obtained at 1 , 2 , and $7 \mathrm{~d}$ after indomethacin administration. ${ }^{18} \mathrm{~F}-\mathrm{FDG}$ uptake in the small intestine was quantified by $\gamma$-counting, and macro- and microautoradiographic studies were performed to determine the site of ${ }^{18} \mathrm{~F}-\mathrm{FDG}$ uptake in tissue and at the cellular level. Results: Ulcers observed in the intestine (mainly in the ileum) 1-4 d after indomethacin administration were most severe at $1 \mathrm{~d}$ after administration and were almost healed at day 7. The PET study showed increased ${ }^{18} \mathrm{~F}$-FDG uptake in the intestine correlating to the severity of ulceration, returning to the basal level on day 7. Ex vivo imaging and $\gamma$-counting showed that these regions of high uptake corresponded to regions of ulceration. A microautoradiographic study combined with immunohistochemistry revealed heavy accumulation of ${ }^{18} \mathrm{~F}-\mathrm{FDG}$ in inflammatory cells containing peroxidase on day 1 and in cells forming granulation tissue $(\alpha$-smooth muscle actin-positive myofibroblasts and ED2-positive macrophages) on days 2-4 in and around ulcers. Proliferating (Ki67-immunopositive) intestinal crypt cells were also densely labeled with ${ }^{18} \mathrm{~F}-\mathrm{FDG}$ in intact intestinal tissue taken from the indomethacin-treated and the control animals. Conclusion: Our experimental data suggest that ${ }^{18} \mathrm{~F}-\mathrm{FDG}$ PET may be useful for evaluating the occurrence of small-intestine ulcers. Ulceration could be visualized early by the prominent uptake of ${ }^{18} \mathrm{~F}-\mathrm{FDG}$ by inflammatory cells and by the formation of granulation tissue by cells in and around ulcers.
\end{abstract}

Key Words: gastroenterology; molecular imaging; animal imaging; ${ }^{18} \mathrm{~F}-\mathrm{FDG}$; PET; indomethacin; intestinal ulceration; microautoradiography

J Nucl Med 2009; 50:266-273

DOI: 10.2967/jnumed.108.057943

Received Sep. 25, 2008; revision accepted Nov. 19, 2008. For correspondence or reprints contact: Yasuyoshi Watanabe, Department of Physiology, Osaka City University Graduate School of Medicine, 1-4-3, Asahimachi, Abeno-ku, Osaka 545-8585, Japan. E-mail: yywata@riken.jp

COPYRIGHT @ 2009 by the Society of Nuclear Medicine, Inc.
$\mathbf{N}$ onsteroidal antiinflammatory drugs (NSAIDs) are the most commonly prescribed drugs worldwide; however, a side effect of conventional NSAIDs, such as indomethacin, is ulceration in the small intestine, caused by suppression of mucosal prostaglandin production via inhibition of cyclooxygenase activity (1-3). Capsule enteroscopy is a recently developed technique that enables direct examination of the entire length of the small intestine; this examination is considered the gold standard for the diagnosis of Crohn disease of the intestine $(4,5)$. Capsule enteroscopy has provided additional information on NSAID-induced intestinal pathology other than Crohn disease. Graham et al. (6) reported that small-intestine mucosal injury was found in $71 \%$ of chronic NSAID users, such as patients with rheumatoid arthritis, and Laurence et al. (7) reported that $68 \%-75 \%$ of volunteers had tissue injury in the small intestine after a 2 -wk period of ingesting diclofenac, an NSAID with omeprazole, a proton pump inhibitor. These studies indicate the high incidence of NSAID-induced enteropathy.

PET coupled with ${ }^{18} \mathrm{~F}-\mathrm{FDG}$, a glucose tracer, has been used clinically in the diagnosis of cancer $(8,9)$ and for the evaluation of anticancer therapeutics (10). The accumulation of ${ }^{18} \mathrm{~F}$-FDG in cancer tissue is thought to reflect enhanced glucose use by neoplastic cells (11-13). ${ }^{18} \mathrm{~F}-\mathrm{FDG}$ accumulation is observed in inflammatory lesions as well as in malignant tumors (14-17). Regarding the gastrointestinal tract, ${ }^{18} \mathrm{~F}$-FDG PET studies have been reported in Crohn disease (18-21). In a PET study, Bicik et al. (18) demonstrated higher ${ }^{18} \mathrm{~F}-\mathrm{FDG}$ uptake in patients in the clinically active state than in those in the inactive state. These clinical reports, however, have not clarified the origin of the ${ }^{18} \mathrm{~F}-\mathrm{FDG}$ signal in tissue or at the cellular level. More recently, genetic murine colitis models were demonstrated by ${ }^{18} \mathrm{~F}$-FDG PET with a flow cytometric study, which indicated that only CD4positive $\mathrm{T}$ lymphocytes accumulated ${ }^{18} \mathrm{~F}-\mathrm{FDG}$ (22). However, no previous studies report using PET to clarify the 
possibility of noninvasive imaging of the course and healing of small-intestine ulceration. In the present study, we noninvasively observed a newly created small-intestine ulceration and its healing using ${ }^{18}$ F-FDG PET. We used macro- and microautoradiographic studies, combined with immunohistochemistry, to identify the origin of the ${ }^{18} \mathrm{~F}-\mathrm{FDG}$ signals, also revealing a transition in signal between the occurrence and healing of the ulcer.

\section{MATERIALS AND METHODS}

\section{Animals}

Male Sprague-Dawley rats (Nippon Charles River; age, 8 wk) were used in all experiments. The rats were housed in a cage with a raised mesh base, under constant environmental conditions (room temperature, $22^{\circ} \mathrm{C}-24^{\circ} \mathrm{C}$; relative humidity, $60 \%-70 \%$ ) and a $12 \mathrm{~h}-12 \mathrm{~h}$ light-dark cycle. Food and water were provided ad libitum. The experimental procedures used in the present study were approved by the Animal Care Committee of the Osaka City University Graduate School of Medicine. All efforts were made to minimize animal suffering and the number of animals used for the studies.

\section{Induction of Small-Intestine Ulceration and Determination of Myeloperoxidase Activity}

Small-intestine ulceration was induced by subcutaneous administration of indomethacin (Sigma-Aldrich) suspended in saline with a drop of polysorbate 80 (ICN Biomedicals Inc.) at a dose of $10 \mathrm{mg} / \mathrm{kg}$. At 1, 2, 4, and $7 \mathrm{~d}$ after indomethacin administration, the rats were euthanized under deep ether anesthesia. To visualize the intestinal lesions, $1 \mathrm{~mL}$ of Evans blue dye (Wako Pure Chemical Industries Ltd.; $1 \%$ w/v) was injected intravenously 30 min before euthanasia in 2-3 indomethacin-administered animals. The small intestine was removed and fixed with $2 \%$ formalin.

Myeloperoxidase activity was measured to evaluate neutrophil infiltration into the intestinal mucosa according to the method reported by Krawisz et al. (23), with some modification. Four to five animals were used on each experimental day (days 1, 2, 4, and 7). The animals were euthanized under deep ether anesthesia at 1 , 2, 4, and $7 \mathrm{~d}$ after indomethacin administration. Blood was then totally withdrawn by perfusion with ice-cold saline through the left ventricle. The small intestine was removed, and the wall along the opposite side of the mesenteric attachment was cut. After the tissue was rinsed with saline, the small intestine was homogenized with a $50 \mathrm{mmol} / \mathrm{L}$ concentration of phosphate buffer containing $0.5 \%$ (w/v) hexadecyl-trimethyl-ammonium bromide (Wako). The homogenized samples were subjected to freezing and thawing 3 times and centrifuged at $2,000 \mathrm{rpm}$ for $10 \mathrm{~min}$ at $4^{\circ} \mathrm{C}$. Supernatant $(100 \mu \mathrm{L})$ was added to $1.9 \mathrm{~mL}$ of $10 \mathrm{mmol} / \mathrm{L}$ phosphate buffer ( $\mathrm{pH} 6.0$ ), to which $1 \mathrm{~mL}$ of $1.5 \mathrm{~mol} / \mathrm{L} o$-dianisine dihydrochloride (Sigma-Aldrich) containing $0.0005 \%(\mathrm{w} / \mathrm{v})$ hydrogen peroxide $\left(\mathrm{H}_{2} \mathrm{O}_{2}\right)$ was added. Absorbance at $450 \mathrm{~nm}$ of each sample was assessed using a spectrophotometer (Beckman Instruments). Protein content was measured using a modified bicinchoninic acid assay method (bicinchoninic acid protein assay reagent kit; Pierce). Myeloperoxidase activity was obtained from the slope of the reaction curve, on the basis of the following equation for specific activity:

$$
\begin{aligned}
\mu \mathrm{mol} \mathrm{H}_{2} \mathrm{O}_{2} / \mathrm{min} / \mathrm{mg} \text { protein }= & (\mathrm{OD} / \mathrm{min}) / \mathrm{OD} / \mu \mathrm{mol} \mathrm{H}_{2} \mathrm{O}_{2} \\
& \times \mathrm{mg} \text { protein. }
\end{aligned}
$$

\section{${ }^{18}$ F-FDG PET}

${ }^{18} \mathrm{~F}$ was produced by the ${ }^{18} \mathrm{O}(\mathrm{p}, \mathrm{n}){ }^{18} \mathrm{~F}$ nuclear reaction in a cyclotron at the Osaka City University, and ${ }^{18} \mathrm{~F}-\mathrm{FDG}$ was synthesized by the method reported by Hamacher et al. (24) using an automated ${ }^{18}$ F-FDG synthesis system (JFE Steel Co.).

We used a small-animal PET scanner (microPET Focus220; Siemens Medical Solutions Inc.) with an animal port (diameter, $220 \mathrm{~mm}$; axial extent, $78 \mathrm{~mm}$; parallel slices, 95; and spatial resolution, $1.7 \mathrm{~mm}$ in full width at half maximum at the center of the field of view). The scanner had a detector system comprising 47 crystal rings made of lutetium oxyorthosilicate; 3-dimensional list-mode data were acquired. At $7 \mathrm{~d}$ before treatment and at 1, 2, and $7 \mathrm{~d}$ after indomethacin administration, PET scans were obtained on 4 rats. ${ }^{18} \mathrm{~F}-\mathrm{FDG}$, at an activity of $55.5 \mathrm{MBq} / \mathrm{kg}$ in $0.3 \mathrm{~mL}$ of saline, was administered to each rat via the tail vein while the animal was conscious. At $45 \mathrm{~min}$ after the ${ }^{18} \mathrm{~F}$-FDG administration, the rats were injected intravenously with propofol (Diprivan; Zeneca) at a dose of $10 \mathrm{mg} / \mathrm{kg}$, followed by continuous infusion at $40 \mathrm{mg} / \mathrm{kg} / \mathrm{h}$ during the PET scan, as previously reported (25). Emission data were then acquired for $20 \mathrm{~min}$, with an energy window of $400-650 \mathrm{keV}$ and a coincidence-timing window of $6 \mathrm{~ns}$. The scanned area was $7.8 \mathrm{~cm}$, from the stomach to the bladder, including the entire intestinal area. From 50 to 70 min after the injection of ${ }^{18} \mathrm{~F}-\mathrm{FDG}$, emission data were sorted into a single-frame sinogram, with a span of 3 and a ring difference of 47, and reconstructed using filtered backprojection and maximum a posteriori algorithms. To clearly visualize the intestinal ulceration, maximum-intensity-projection images of the maximum a posteriori-reconstructed images were displayed using ASIPro software (version 4.10; Concorde Microsystems).

In our model of indomethacin-induced small-intestine ulcers, the diameter of each ulcer was approximately $1.0-1.5 \mathrm{~mm}$ (data not shown). Consequently, circular regions of interest (ROIs) (diameter, $1 \mathrm{~mm}$ ) were drawn on the abdominal area (except the kidney, bladder, or bone) in the filtered backprojection-reconstructed images, using PMOD (version 2.75; PMOD Technologies Ltd.). A total of 7-8 ROIs were selected from the most intense signal in 7 consecutive filtered backprojection-reconstructed images from each animal. The ROI values were averaged to produce mean standardized uptake values (SUVs) based on the following equation for quantitative comparison of ${ }^{18} \mathrm{~F}-\mathrm{FDG}$ uptake. The mean SUV obtained from 50 to 60 ROIs was used as the data for each animal. These data were plotted against time (days) after indomethacin administration:

$$
\begin{aligned}
\mathrm{SUV}= & \text { mean ROI value }(\mathrm{MBq} / \mathrm{mL}) / \\
& \{\text { injected activity }(\mathrm{MBq}) / \text { body weight }(\mathrm{g})\}
\end{aligned}
$$

\section{$\gamma$-Counting Study}

Healthy rats and those with ulcers (1 d after indomethacin administration) were injected with ${ }^{18} \mathrm{~F}-\mathrm{FDG}$ at a dose of 55.5 $\mathrm{MBq} / \mathrm{kg}$ via the tail vein. Rats ( $n=4-6$ animals in each group) were euthanized at $5,15,30,45$, and $90 \mathrm{~min}$ after ${ }^{18} \mathrm{~F}-\mathrm{FDG}$ injection under deep ether anesthesia. A 5-cm length of ileum was taken from the region 5-20 cm above the colon, washed with 
saline, and weighed. Radioactivity of ${ }^{18} \mathrm{~F}-\mathrm{FDG}$ in each sample was counted using an auto-well $\gamma$-counting system (ARC-2000; ALOKA Co. Ltd.). In addition, we evaluated radioactivity at 45 min after ${ }^{18}$ F-FDG injection among the different time intervals (1, 2,4 , and $7 \mathrm{~d}$ after injection of indomethacin). The amount of radioactivity in each tissue was calculated as the percentage injected dose per gram of tissue (\%ID/g).

\section{Macroautoradiography}

Macroautoradiography was performed using a modified method described in our previous study, as reported by Matsumura et al. (25). Briefly, ${ }^{18} \mathrm{~F}-\mathrm{FDG}(55.5 \mathrm{MBq} / \mathrm{kg})$ in $0.3 \mathrm{~mL}$ of physiologic saline was administered to rats via the tail vein. At $45 \mathrm{~min}$ after administration, the rats were deeply anesthetized with diethyl ether and then euthanized, and the blood was totally withdrawn by perfusing saline through the left ventricle. The small intestine was then rapidly removed, washed with saline, and placed on an imaging plate (BAS-IV MS 2040; Fuji Photo Film) for $20 \mathrm{~min}$. The plate was scanned with a bioimaging analyzer (BAS-5000; Fuji Photo Film), and the images were displayed by Image Gauge software (version 4.2.1; Fuji Photo Film).

\section{Microautoradiography Combined with Immunohistochemistry}

Microautoradiography was performed using a modified method reported by Kubota et al. (26). Briefly, healthy rats and those with ulcers were injected intravenously with ${ }^{18}$ F-FDG (74 MBq). They were euthanized under deep ether anesthesia at $45 \mathrm{~min}$ after the administration. Blood was totally withdrawn by perfusing saline through the left ventricle. The small intestine was quickly dissected and frozen with dry ice. Under a safety light, 5 - $\mu \mathrm{m}$-thick sections were made and mounted on slides coated with NTB2 nuclear emulsion (Kodak) diluted 13:7 with distilled water. The slides were immediately frozen on a dry ice block and kept in exposure boxes cooled with dry ice. After a 6-h exposure, sections were transferred to ethanol and acetic acid (ratio, 19:1) at $-70^{\circ} \mathrm{C}$ and $25^{\circ} \mathrm{C}$ for $1 \mathrm{~min}$ each. After washing with water twice for $3 \mathrm{~min}$, the sections were developed in D-19 developer (Kodak) for $5 \mathrm{~min}$, fixed in Fuji Fix (Fuji Photo Film) for $15 \mathrm{~min}$ at room temperature, and then washed in water for $10 \mathrm{~min}$.

In the combined microautoradiography and immunohistochemistry study, sections were fixed by $4 \%$ paraformaldehyde at $4{ }^{\circ} \mathrm{C}$ for $3 \mathrm{~min}$ after development and fixation for microautoradiography. We inactivated the endogenous peroxidase by immersing the sections in $0.3 \% \mathrm{H}_{2} \mathrm{O}_{2}$ in isotonic phosphate-buffered saline with $0.3 \%$ Triton X-100 (PBS-T) (Sigma-Aldrich) at room temperature for at least $2 \mathrm{~h}$ and then washing the sections with PBS-T 3 times for $5 \mathrm{~min}$ each. After immersing the sections in a blocking solution (3\% normal serum in PBS-T) at room temperature for $1 \mathrm{~h}$, we incubated the sections with each antibody at $4^{\circ} \mathrm{C}$ for $18 \mathrm{~h}$ as follows: monoclonal antibodies against rat CD31 (an endothelial cell marker; BD Biosciences Pharmingen) (1:200 dilution), rat ED2 (a macrophage marker; Serotec Ltd.) (1:100 dilution), and human $\alpha$-smooth muscle actin ( $\alpha$-SMA, a myofibroblast marker; R\&D Systems) (1:200 dilution), and a polyclonal antibody against Ki67 (a proliferation marker; Novocastra Laboratories) (1:1,000 dilution). After we washed the sections in PBS-T 3 times, we incubated them with biotinylated antimouse or antirabbit $\mathrm{IgG}$ (Vector Laboratories; 1:400 dilution) at room temperature for $4 \mathrm{~h}$, washed them with PBS-T 3 times, and then incubated them with peroxidase-labeled streptavidin (Vectastain; Vector Laboratories) at room temperature for $1 \mathrm{~h}$. These immunoreactions were visualized by the reaction with 3,3'-diaminobenzidine (Wako) and $0.03 \% \mathrm{H}_{2} \mathrm{O}_{2}$. Counterstaining was performed with Mayer's hematoxylin.

\section{Statistical Analysis}

Parametric data are presented as mean \pm SD. Statistical significance was determined using a 2-tailed Student $t$ test. A $P$ value of less than 0.05 was considered to be statistically significant.

\section{RESULTS}

\section{Induction of Indomethacin-Induced Intestinal Ulcer} and Myeloperoxidase Activity Assay

Administration of indomethacin $(10 \mathrm{mg} / \mathrm{kg})$ caused small-intestine ulceration on the side of the mesenteric attachment $24 \mathrm{~h}$ after administration, mainly in the ileum. Intestinal ulcers were most severe at day 1 (24 h after indomethacin administration), after which gradual healing was observed (Fig. 1A). Macroscopically, ulcers were almost healed in $7 \mathrm{~d}$ (Fig. 1A). Histologic observation revealed denuded epithelium and severe edema in the submucosa on day 1. Granulation tissue was clearly observed on the ulcer bed on day 4, and neoepithelial cells covered the damaged areas on day 7 (Fig. 1B). These macro- and microscopic observations are consistent with a report by Hatazawa et al. (27).

To evaluate the severity of ulceration by quantifying infiltration of neutrophils, myeloperoxidase activity was assayed in the small-intestine mucosa. In the control group (Fig. 1C), little myeloperoxidase activity was detected in the intestine $\left(<0.01 \mu \mathrm{mol} \mathrm{H}_{2} \mathrm{O}_{2} / \mathrm{mg}\right.$ protein). On day 1 , myeloperoxidase activity was markedly elevated $(0.38 \pm 0.04$ $\mu \mathrm{mol} \mathrm{H}_{2} \mathrm{O}_{2} / \mathrm{mg}$ protein), a value significantly higher than that of the control group $(P<0.01)$. Myeloperoxidase activity began to decline on day $2\left(0.21 \pm 0.10 \mu \mathrm{mol} \mathrm{H}_{2} \mathrm{O}_{2} / \mathrm{mg}\right.$ protein $[P<0.05]$ on day 2 and $0.04 \pm 0.01 \mu \mathrm{mol} \mathrm{H}_{2} \mathrm{O}_{2} / \mathrm{mg}$ $[P<0.05]$ on day 4$)$, and activity was negligible on day 7 $\left(<0.01 \mu \mathrm{mol} \mathrm{H}_{2} \mathrm{O}_{2} / \mathrm{mg}\right.$ protein $)$.

\section{$\gamma$-Counting Study}

${ }^{18} \mathrm{~F}-\mathrm{FDG}$ accumulation in the small intestine on day 1 after indomethacin administration was evaluated by $\gamma$-counting using small intestines taken at 5, 15, 30, 45, and $90 \mathrm{~min}$ after ${ }^{18}$ F-FDG injection (Supplemental Fig. 1; supplemental materials are available online only at http:// jnm.snmjournals.org). Accumulation in the intestines with ulcers reached a maximum at $45 \mathrm{~min}$ after ${ }^{18} \mathrm{~F}-\mathrm{FDG}$ injection, before decreasing. In contrast, ${ }^{18} \mathrm{~F}-\mathrm{FDG}$ uptake in control animals injected with vehicle alone peaked 5 min after ${ }^{18} \mathrm{~F}-\mathrm{FDG}$ injection, before decreasing.

In the course of small-intestine ulceration and healing for the $7 \mathrm{~d}$ after indomethacin administration, $\gamma$-counting was performed $45 \mathrm{~min}$ after the injection on days 1, 2, 4, and 7 in indomethacin-treated and control (vehicle-injected) rats (Fig. 2). In indomethacin-treated rats, the highest value was observed on day $1(1.05 \pm 0.37 \% \mathrm{ID} / \mathrm{g}, n=6$ animals $)$, 
A

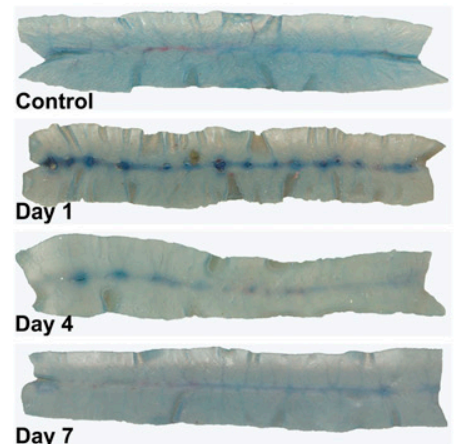

Day 7
B

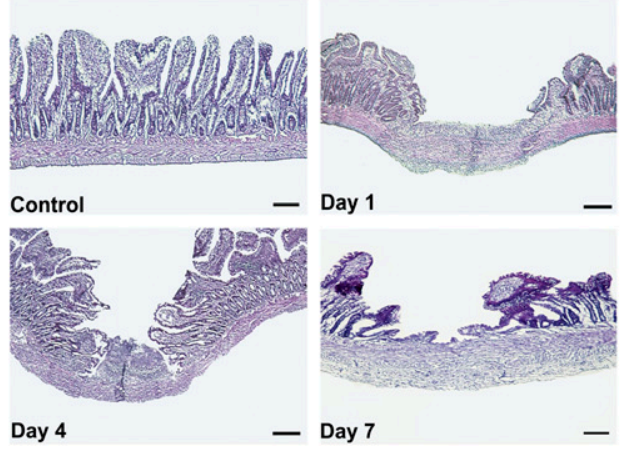

C

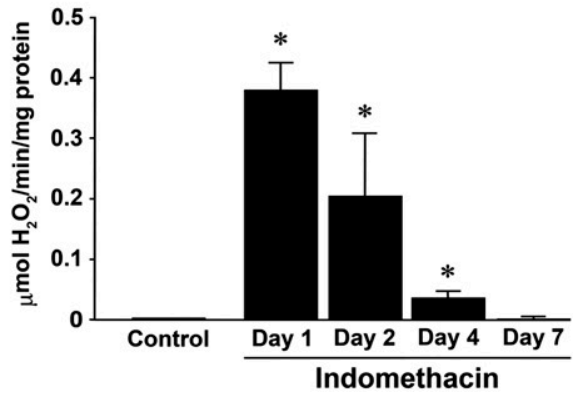

FIGURE 1. Macroscopic (A) and microscopic (B) observations of indomethacin-induced small-intestine ulceration during healing in rats. (A) Continuous circular lesions were seen on side of mesenteric attachment on day 1 or 4 . (B) Histologically, denuded epithelium and severe edema in submucosa (day 1), granulation tissue on ulcer bed (day 4), and neoepithelial cells (day 7) were observed (hematoxylin and eosin staining; scale bar, $200 \mu \mathrm{m}$ ). (C) Change in myeloperoxidase activity as marker of neutrophil infiltration during indomethacin-induced intestinal ulceration and healing. Myeloperoxidase activity was evaluated in animals after administration of indomethacin (days 1, 2, 4, and 7) and in vehicle-injected animals (control). Data are shown as mean \pm SD; $n=4-5$ animals. ${ }^{*} P<0.05$.

after which the values gradually decreased $(0.78 \pm 0.17$ $\% \mathrm{ID} / \mathrm{g}, n=6$ animals on day 2 and $0.55 \pm 0.15 \% \mathrm{ID} / \mathrm{g}, n=$ 6 animals on day 4), returning to the value of $0.21 \pm 0.12$ $\% \mathrm{ID} / \mathrm{g}$ on day 7 (the same level as in the control rats $[0.25 \pm$ $0.07 \% \mathrm{ID} / \mathrm{g}, n=4$ animals]).

\section{Small-Animal PET Study}

In the ${ }^{18}$ F-FDG PET study, specific ${ }^{18}$ F-FDG accumulation was visualized and quantified in coronal images of the abdominal areas of 4 rats in the course of small-intestine ulceration and healing for $7 \mathrm{~d}$ after indomethacin administration (Fig. 3). Over the course of the experiment, accumulations were commonly observed in the kidney and urinary bladder. On day 1 , robust tubelike signals were

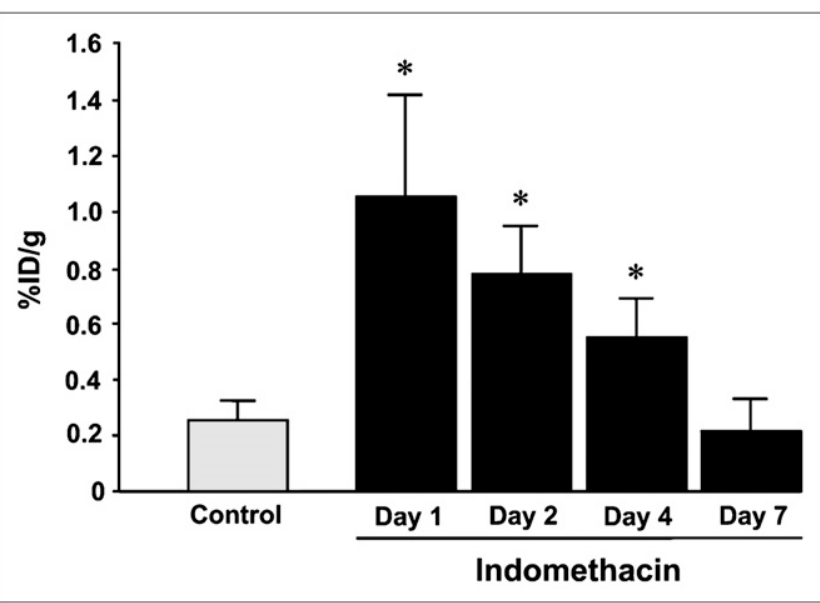

FIGURE 2. $\gamma$-counting study of ${ }^{18} \mathrm{~F}$-FDG uptake in ulcerated intestine, showing ${ }^{18} \mathrm{~F}-\mathrm{FDG}$ accumulation in small intestine at time points after indomethacin administration (days 1, 2, 4, and 7 ) and after vehicle injection (control). Data are shown as mean $\pm \mathrm{SD} ; n=6-8$ animals for each time point. seen in the abdominal area (Fig. 3A, arrowhead). Similar but weak signals were seen on day 2 . These specific signals finally disappeared on day 7 (Fig. 3A).

Figure 3B indicates the mean SUV in the abdominal areas of the animals on each experimental day of the ${ }^{18} \mathrm{~F}$ FDG PET study. SUV was highest on day $1(2.16 \pm 0.28$, $P<0.01)$, began to decrease on day $2(1.91 \pm 0.87, P<$ $0.05)$, and returned to the pretreatment level $(0.70 \pm 0.08)$ on day $7(0.91 \pm 0.17)$, consistent with the findings of the $\gamma$-counting study.

\section{Macroautoradiography}

The autoradiography findings were analyzed for ex vivo confirmation of the region of ${ }^{18}$ F-FDG accumulation in the small intestine (Fig. 4). In the control group (injected with vehicle alone), low and uniform distribution of ${ }^{18} \mathrm{~F}-\mathrm{FDG}$ was observed throughout the intestine. On day 1 after indomethacin administration, discontinuous dotlike accumulation was clearly identified, mainly in the ileum. In the specimen opened along the longitudinal axis, intensive accumulation of ${ }^{18}$ F-FDG was observed at the mesenteric side of the intestinal mucosa in which ulceration was observed (Fig. 4, arrowhead). On day 7, the ${ }^{18}$ F-FDG imaging profile was similar to that of the control.

\section{Microautoradiography Combined with Immunohistochemistry}

Microautoradiography of the intestine was performed to identify ${ }^{18} \mathrm{~F}-\mathrm{FDG}$ accumulation at the cellular level (Figs. 5 and 6). In animals injected with indomethacin, labeling with silver grains of a high density was observed in ulcerated areas, especially in the submucosal and smooth muscle layers on day 1 (Figs. 5A-5C). Combined with peroxidase staining, silver grains were seen in the ulcerated 
A
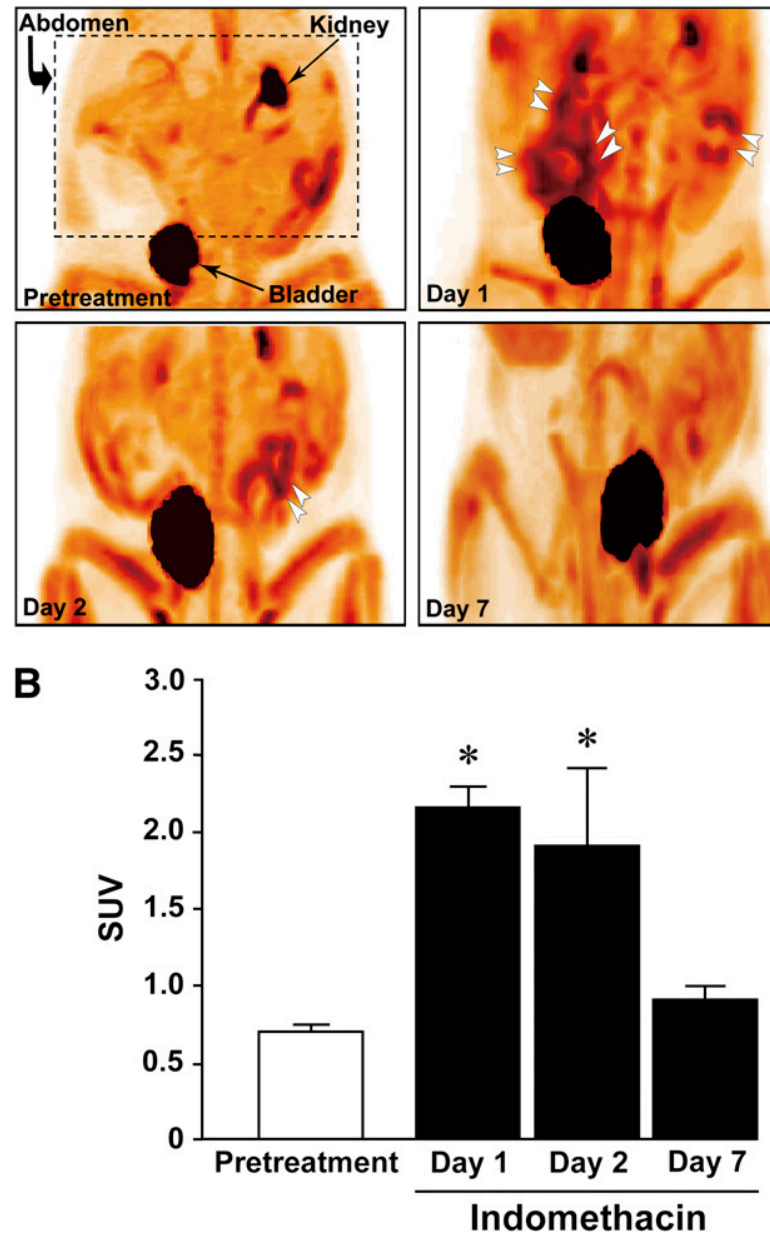

FIGURE 3. ${ }^{18}$ F-FDG PET study of indomethacin-induced intestinal ulceration. (A) Abdominal PET images (coronal images) in same rat at different times after indomethacin administration. Arrowheads indicate characteristic accumulation of ${ }^{18} \mathrm{~F}-\mathrm{FDG}$. (B) Quantification of ${ }^{18} \mathrm{~F}-\mathrm{FDG}$ uptake in PET study. Mean SUVs are shown as mean \pm SD; $n=4$ animals. ${ }^{\star} P<0.05$.

area that included the majority of the peroxidase-positive cells (Figs. 6A and 6B).

On day 4, dense labeling with silver grains was seen on cells forming granulation tissue (Figs. 5D and 5E). In granulation tissue, combined microautoradiography and immunohistochemistry revealed silver grains localized on the cytoplasm of $\alpha$-SMA-positive myofibroblasts, a few ED2-positive macrophages, and CD31-positive endothelial cells (Figs. 6C-6E).

${ }^{18}$ F-FDG accumulation was observed not only in the intestinal crypts and around ulcerated areas but also in the intact region of the intestine. The microautoradiographic study combined with immunohistochemical detection of Ki67, a cell cycle marker, revealed that such an accumulation of ${ }^{18} \mathrm{~F}$-FDG was involved in many proliferating cells in the crypts (Fig. 6F).

\section{DISCUSSION}

In recent years, the usability of ${ }^{18} \mathrm{~F}$-FDG PET has been reported for the detection of malignant and inflammatory diseases, including those of the gastrointestinal tract (1821,28-30); however, the relationship between ${ }^{18} \mathrm{~F}-\mathrm{FDG}$ uptake and the condition of gastrointestinal ulceration remains unclear.

Subcutaneous administration of indomethacin, a representative NSAID $(10 \mathrm{mg} / \mathrm{kg})$, caused small-intestine ulceration on the mesenteric attachment side, mainly in the ileum, with ulceration almost healed in $1 \mathrm{wk}$, as previously shown in macro- and microscopic observations reported by Hatazawa et al. (27). In the present PET study, we used propofol 4 times (before treatment and on days 1,2, and 7) to anesthetize each rat. Propofol is known to modulate gamma-aminobutyric acid (GABA)-ergic transmission and exerts its pharmacologic effects by enhancing the function of the GABA-activated chloride channels (31). Therefore, we cannot rule out the possibility that feeding behavior and locomotor activity were affected during the experiment. The dose used in this study, however, did not affect the severity or healing of the intestinal ulcers (data not shown).

In the present study, characteristic abdominal ${ }^{18} \mathrm{~F}-\mathrm{FDG}$ uptake was observed in indomethacin-induced ulceration, with maximum uptake observed $1 \mathrm{~d}$ after indomethacin administration. We used SUV to quantify ${ }^{18} \mathrm{~F}$-FDG uptake in the PET study. The mean SUV was approximately 3 times greater in the indomethacin treatment group than in the pretreatment group on day 1 and returned to the pretreatment level on $7 \mathrm{~d}$. This time course of ulceration was also confirmed by $\gamma$-counting. Our data showed the ulcerated areas to have an ${ }^{18}$ F-FDG SUV of $2.16 \pm 0.28$, compared with $0.70 \pm 0.08$ for the normal areas $(P<$ 0.01 ). Therefore, a threshold SUV of 1.60 (mean -2 SDs) could be applied for PET evaluation of tissue suspected of being ulcer-positive. These findings indicated that ${ }^{18} \mathrm{~F}-\mathrm{FDG}$ PET could evaluate not only the severity but also the process of healing on indomethacin-induced intestinal ulceration. Thus, ${ }^{18} \mathrm{~F}-\mathrm{FDG}$ PET could be useful for noninvasive detection of gastrointestinal ulcers and in follow-up, even in the clinical cases.

The microautoradiographic study provided an understanding of tissue ${ }^{18} \mathrm{~F}-\mathrm{FDG}$ accumulation at the cellular level. One day after administration of indomethacin (when the mucosal lesions were most severe), marked ${ }^{18} \mathrm{~F}$-FDG accumulations were observed at the marginal, submucosal, and muscular regions of ulceration. These regions contained many peroxidase-positive cells, suggesting that ${ }^{18} \mathrm{~F}-$ FDG accumulated in inflammatory cells such as neutrophils and macrophages. On day 4, the number of peroxidasepositive inflammatory cells decreased, and granulation tissue was formed on the ulcer bed. Accumulation of ${ }^{18} \mathrm{~F}-\mathrm{FDG}$ was found in the granulation tissue. The microautoradiographic study, combined with immunohistochemistry, revealed that ${ }^{18} \mathrm{~F}$-FDG accumulation was observed in $\alpha$-SMA-positive 


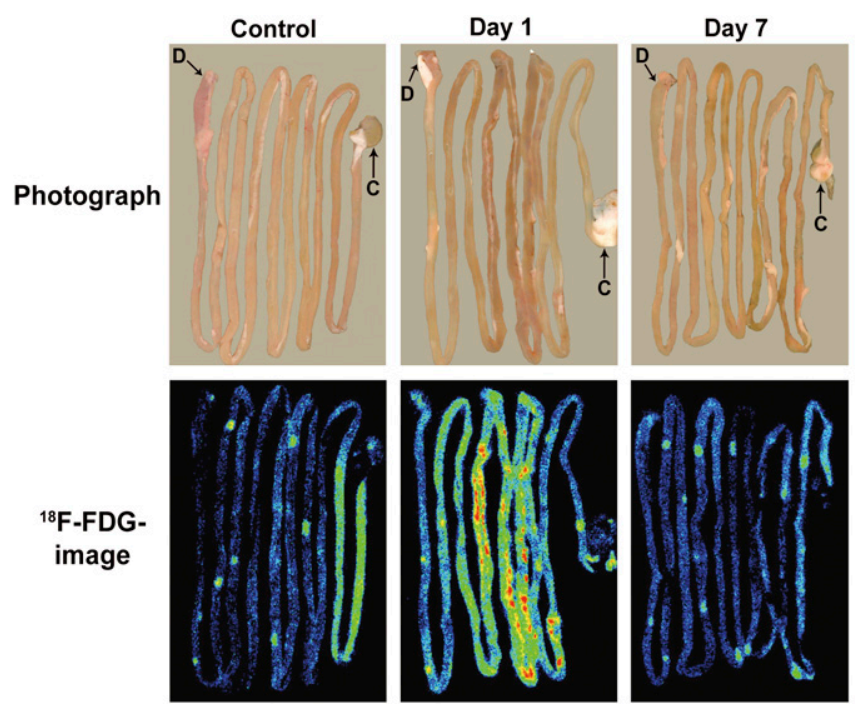

myofibroblasts, CD31-positive endothelial cells, and a few ED2-positive macrophages.

Myofibroblasts are thought to play an important role in the repair of injured gut $(32,33)$; contraction of intestinal myofibroblasts rapidly reduces mucosal defects and decreases the area requiring reepithelialization (33). CD31immunopositive endothelial cells are also well known to play an important role in ulcer healing by angiogenesis $(34,35)$. Kubota et al. (36) reported that ${ }^{18}$ F-FDG accumulation in macrophages and neutrophils likely occurred via the use of glucose as the energy source for their chemotaxis and phagocytosis and in fibroblasts for proliferation in and around tumors, although those ${ }^{18} \mathrm{~F}-\mathrm{FDG}$-accumulated cells were not identified immunohistochemically. These observations support the findings of the present study obtained by microautoradiography combined with immunohistochemical identification of cells.

In addition to cells with accumulated ${ }^{18} \mathrm{~F}-\mathrm{FDG}$, we found that cells located in deeper regions of the intestinal crypts, and in normal tissue, were heavily radiolabeled with ${ }^{18} \mathrm{~F}-$ FDG. The combination study of ${ }^{18}$ F-FDG microautoradiography with immunohistochemistry revealed that the cells

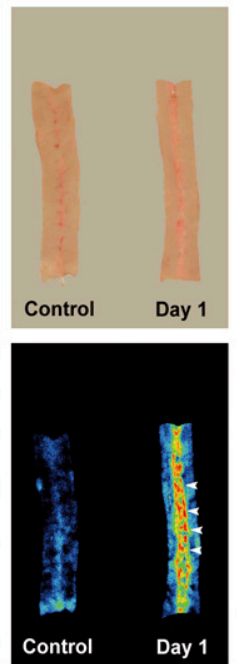

FIGURE 4. ${ }^{18}$ F-FDG macroautoradiography of intestinal ulceration. Rats were intravenously injected with ${ }^{18} \mathrm{~F}-\mathrm{FDG}$ and euthanized $45 \mathrm{~min}$ later. Discontinuous dotlike ${ }^{18} \mathrm{~F}-\mathrm{FDG}$ accumulation was clearly identified mainly in ileum on day $1 .{ }^{18} \mathrm{~F}-\mathrm{FDG}$ imaging profile was similar to that of control on day 7 . Images at far right show plain photograph (upper) and ${ }^{18} \mathrm{~F}-\mathrm{FDG}$ image (lower) of intestines opened along longitudinal axis for control and at day 1. $\mathrm{D}=$ duodenum; $\mathrm{C}=$ cecum.

were immunopositive for Ki67. Such regions of the intestinal crypts are known to contain many intestinal stem cells expressing Ki67 (37). The stem cells actively proliferate and differentiate mainly into absorptive cells, the major constituent of the epithelial cells of the villus, migrating upward along the crypt-villus axis $(38,39)$. These findings indicate that proliferating cells in the intestinal epithelium actively take up ${ }^{18}$ F-FDG. Ki67 is known to be included in the granular components of the nucleolus during late $\mathrm{G} 1, \mathrm{~S}$, G2, and M phases (40); therefore, additional studies using cell cycle markers are required to understand the relationship between each cell cycle phase and glucose utility. To the best of our knowledge, the present study is the first to show ${ }^{18} \mathrm{~F}$-FDG uptake at the single-cell level by a combination of microautoradiography and immunohistochemistry. Our results indicated that ${ }^{18} \mathrm{~F}-\mathrm{FDG}$ accumulates in such inflammatory cells during the acute phase of mucosal ulceration and also in the cells forming granulation during the healing phase.

NSAIDs, some of the most commonly prescribed drugs worldwide for antipyresis and analgesia, act by inhibition of endogenous prostaglandin synthesis. Prostaglandins are well known to maintain the mucosal integrity of the gastrointes-

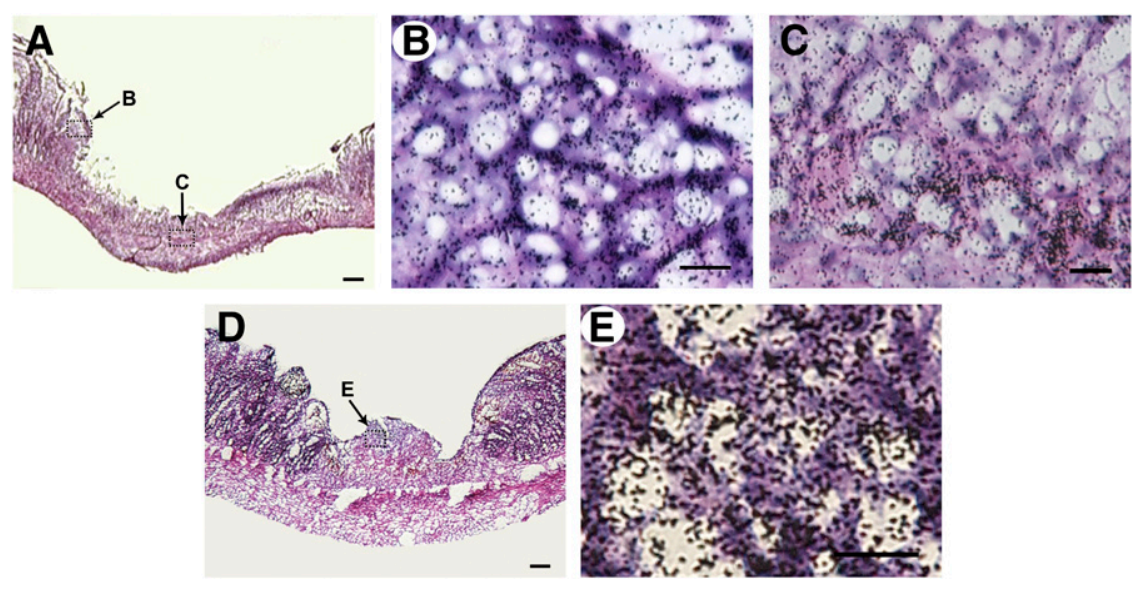

FIGURE 5. ${ }^{18}$ F-FDG microautoradiography of indomethacin-induced intestinal lesions combined with hematoxylin and eosin staining. (A-C) At $1 \mathrm{~d}$ after administration of indomethacin, silver grains of high density were observed in ulcerated area, especially at ulcer margin (B) and submucosal and smooth muscle layer (C). B and $C$ are magnified views of areas indicated by arrows $B$ and $C$ in $A$. (D and $E$ ) On day 4, grains were accumulated on cells forming granulation tissue. (E) Magnified view of the region indicated by arrow $E$ in $D$. Scale bars: $100 \mu \mathrm{m}(A$ and $D)$ and 20 $\mu \mathrm{m}(\mathrm{B}, \mathrm{C}$, and $\mathrm{E})$. 
FIGURE 6. Microautoradiography combined with immunohistochemistry. In submucosal area at day 1 after indomethacin administration, ${ }^{18}$ F-FDG uptake was observed mainly in peroxidasepositive cells (A and $B$ ). On granulation tissue at day 4 , myofibroblasts (C; $\alpha$-SMA-positive), macrophages (D; ED2positive), and endothelial cells ( $\mathrm{E}$; CD31positive) were visualized. In normal tissue, silver grains of high density reflecting ${ }^{18} \mathrm{~F}-\mathrm{FDG}$ radioactivity were observed in Ki67-positive crypt cells (F). Insets show magnified view of region indicated by arrowheads in each panel. Scale bars: $100 \mu \mathrm{m}(\mathrm{A}), 10 \mu \mathrm{m}(\mathrm{B})$, and $5 \mu \mathrm{m}(\mathrm{C}-\mathrm{F})$.
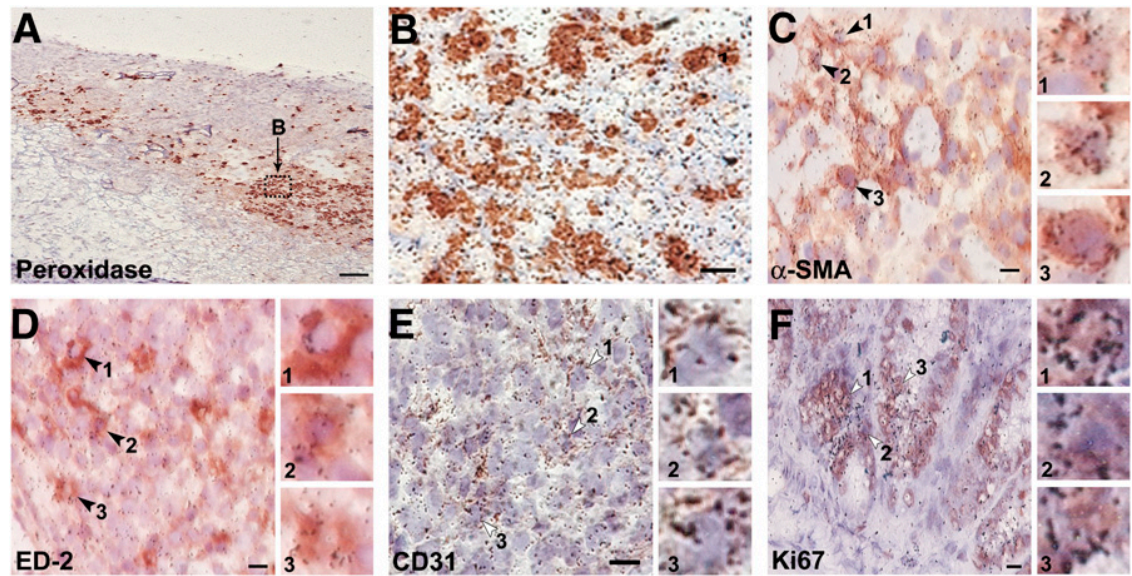

tinal tract; therefore, NSAIDs commonly cause gastrointestinal damage as an adverse effect. The recently developed technique of capsule enteroscopy has enabled examination of damage to the small bowel and is now considered the gold standard for diagnosis of Crohn disease of the intestine $(4,5)$. However, in this technique, the images are magnified to differing extents depending on the amount of surrounding fluid, making it difficult to evaluate lesion size (7). Furthermore, capsule enteroscopy carries a risk of capsule retention if there is obstruction of the digestive tract, which may occur in intestinal disorders. In the present study, we demonstrated the usability of ${ }^{18}$ F-FDG PET and also the meaning of physiologic and pathologic glucose uptake for indomethacininduced intestinal ulceration. Because ${ }^{18}$ F-FDG PET is used clinically for diagnosis of cancer or tumors and has low adverse effects, the safety of the method for patients is well established. Clinical studies are needed to evaluate whether ${ }^{18} \mathrm{~F}-\mathrm{FDG}$ PET exhibits sufficient sensitivity and specificity for the detection of indomethacin-induced small-intestine ulcers in humans. ${ }^{18}$ F-FDG PET will enable detection of intestinal lesions, staging of disease, and assessment of clinical treatment and reveal recurrence of disease.

\section{CONCLUSION}

Our experimental data suggest that ${ }^{18}$ F-FDG PET may be useful for evaluating indomethacin-induced small-intestine ulcers. ${ }^{18}$ F-FDG accumulation was observed mainly in inflammatory cells in the acute phase and in myofibroblasts and endothelial cells forming granulation tissue in the healing phase. PET enables detection of accumulation during the course of ulceration.

\section{ACKNOWLEDGMENTS}

We thank the staff of Osaka City University Hospital for ${ }^{18} \mathrm{~F}-\mathrm{FDG}$ synthesis and provision; the staff of the radioisotope center, Osaka City University Graduate School of Medicine, for their cooperation; Kaori Okuyama for technical assistance; and Dr. Annabel Boyes for the editorial help.
This work was supported by a consignment expense for the Molecular Imaging Program on Research Base for Exploring New Drugs from the Ministry of Education, Culture, Sports, Science and Technology (MEXT), Japanese government.

\section{REFERENCES}

1. Robert A, Asano T. Resistance of germ-free rats to indomethacin-induced intestinal inflammation. Prostaglandins. 1977;14:333-341.

2. Fang WF, Broughton A, Jacobson ED. Indomethacin induced intestinal inflammation. Am J Dig Dis. 1977;22:749-760.

3. Bjarnason I, Zanelli G, Smith T, et al. Nonsteroidal anti-inflammatory druginduced intestinal inflammation in humans. Gastroenterology. 1987;93:480-489.

4. Marmo R, Rotondano G, Piscopo R, et al. Capsule endoscopy versus enteroclysis in the detection of small-bowel involvement in Crohn's disease: a prospective trial. Clin Gastroenterol Hepatol. 2005;3:772-776.

5. Girelli CM, Porta P, Malacrida V, Barzaghi F, Rocca F. Clinical outcome of patients examined by capsule endoscopy for suspected small bowel Crohn's disease. Dig Liver Dis. 2007;39:148-154.

6. Graham DY, Opekun AR, Willingham FF, Qureshi WA. Visible small-intestinal mucosal injury in chronic NSAID users. Clin Gastroenterol Hepatol. 2005;3:55-59.

7. Maiden L, Thjodleifsson B, Theodors A, Gonzalez J, Bjarnason I. A quantitative analysis of NSAID-induced small bowel pathology by capsule enteroscopy. Gastroenterology. 2005;128:1172-1178.

8. Dang CV, Semenza GL. Oncogenic alterations of metabolism. Trends Biochem Sci. 1999;24:68-72.

9. Gambhir SS, Czernin J, Schwimmer J, Silverman DH, Coleman RE, Phelps ME. A tabulated summary of the FDG PET literature. J Nucl Med. 2001;42(5 suppl): 1S-93S

10. Price P. Changes in ${ }^{18} \mathrm{~F}-\mathrm{FDG}$ uptake measured by PET as pharmacodynamic endpoint in anticancer therapy: how far have we got? Br J Cancer. 2000;83:281-283.

11. McKeehan WL. Glycolysis, glutaminolysis and cell proliferation. Cell Biol Int Rep. 1982;6:635-650.

12. Weber G, Morris HP, Love WC, Ashmore J. Comparative biochemistry of hepatomas. II. Isotope studies of carbohydrate metabolism in Morris hepatoma 5123. Cancer Res. 1961;21:1406-1411.

13. Weber G. Enzymology of cancer cells. N Engl J Med. 1977;296:541-551.

14. Bakheet SM, Saleem M, Powe J, Al-Amro A, Larsson SG, Mahassin Z. F-18 fluorodeoxyglucose chest uptake in lung inflammation and infection. Clin Nucl Med. 2000;25:273-278.

15. Hustinx R, Smith RJ, Benard F, et al. Dual time point fluorine-18 fluorodeoxyglucose positron emission tomography: a potential method to differentiate malignancy from inflammation and normal tissue in the head and neck. Eur J Nucl Med. 1999;26:1345-1348.

16. Shreve PD. Focal fluorine-18 fluorodeoxyglucose accumulation in inflammatory pancreatic disease. Eur J Nucl Med. 1998;25:259-264.

17. Ichiya Y, Kuwabara Y, Sasaki M, et al. FDG-PET in infectious lesions: the detection and assessment of lesion activity. Ann Nucl Med. 1996;10:185-191.

18. Bicik I, Bauerfeind P, Breitbach T, von Schulthess GK, Fried M. Inflammatory bowel disease activity measured by positron-emission tomography [abstract]. Lancet. 1997;350:262. 
19. Neurath MF, Vehling D, Schunk K, et al. Noninvasive assessment of Crohn's disease activity: a comparison of ${ }^{18} \mathrm{~F}$-fluorodeoxyglucose positron emission tomography, hydromagnetic resonance imaging, and granulocyte scintigraphy with labeled antibodies. Am J Gastroenterol. 2002;97:1978-1985.

20. Lemberg DA, Issenman RM, Cawdron R, et al. Positron emission tomography in the investigation of pediatric inflammatory bowel disease. Inflamm Bowel Dis. 2005;11:733-738.

21. Louis E, Ancion G, Colard A, Spote V, Belaiche J, Hustinx R. Noninvasive assessment of Crohn's disease intestinal lesion with ${ }^{18}$ F-FDG PET/CT. $J$ Nucl Med. 2007;48:1053-1059.

22. Brewer S, McPherson M, Fujiwara D, et al. Molecular imaging of murine intestinal inflammation with 2-deoxy-2-[ $\left.{ }^{18} \mathrm{~F}\right]$ fluoro-D-glucose and positron emission tomography. Gastroenterology. 2008;135:744-755.

23. Krawisz JE, Sharon P, Stenson WF. Quantitative assay for acute intestinal inflammation based on myeloperoxidase activity: assessment of inflammation in rat and hamster models. Gastroenterology. 1984;87:1344-1350.

24. Hamacher K, Coenen HH, Stocklin G. Efficient stereospecific synthesis of nocarrier-added 2-[ $\left.{ }^{18} \mathrm{~F}\right]$-fluoro-2-deoxy-D-glucose using aminopolyether supported nucleophilic substitution. J Nucl Med. 1986;27:235-238.

25. Matsumura A, Mizokawa S, Tanaka M, et al. Assessment of microPET performance in analyzing the rat brain under different types of anesthesia: comparison between quantitative data obtained with microPET and ex vivo autoradiography. Neuroimage. 2003;20:2040-2050.

26. Kubota R, Yamada S, Kubota K, Ishiwata K, Tamahashi N, Ido T. Intratumoral distribution of fluorine-18-fluorodeoxyglucose in vivo: high accumulation in macrophages and granulation tissues studied by microautoradiography. $\mathrm{J} \mathrm{Nucl}$ Med. 1992;33:1972-1980.

27. Hatazawa R, Ohno R, Tanigami M, Tanaka A, Takeuchi K. Roles of endogenous prostaglandins and cyclooxygenase isozymes in healing of indomethacin-induced small intestinal lesions in rats. J Pharmacol Exp Ther. 2006;318:691-699.

28. Annovazzi A, Peeters M, Maenhout A, Signore A, Dierckx R, Van De Wiele C. 18fluorodeoxyglucose positron emission tomography in nonendocrine neoplastic disorders of the gastrointestinal tract. Gastroenterology. 2003;125:1235-1245.
29. Chin BB, Wahl RL. ${ }^{18}$ F-Fluoro-2-deoxyglucose positron emission tomography in the evaluation of gastrointestinal malignancies. GUT. 2003;52(suppl 4): 23-29.

30. Kresnik E, Gallowitsch HJ, Mikosch P, et al. ${ }^{18} \mathrm{~F}-\mathrm{FDG}$ positron emission tomography in the early diagnosis of enterocolitis: preliminary results. Eur $J$ Nucl Med Mol Imaging. 2002;29:1389-1392.

31. Concas A, Santoro G, Mascia MP, Serra M, Sanna E, Biggio G. The general anesthetic propofol enhances the function of gamma-aminobutyric acid-coupled chloride channel in the rat cerebral cortex. J Neurochem. 1990;55:2135-2138.

32. Powell DW, Adegboyega PA, Di Mari JF, Mifflin RC. Epithelial cells and their neighbors. I. Role of intestinal myofibroblasts in development, repair and cancer. Am J Physiol Gastrointest Liver Physiol. 2005;289:G2-G7.

33. Powell DW, Mifflin RC, Valentich JD, Crowe SE, Saada JI, West AB. Myofibroblasts. II. Intestinal subepithelial myofibroblasts. Am J Physiol. 1999;277: C183-C201.

34. DeLisser HM, Christofidou-Solomidou M, Strieter RM, et al. Involvement of endothelial PECAM-1/CD31 in angiogenesis. Am J Pathol. 1997;151:671-677.

35. Hudson N, Balsitis M, Everitt S, Hawkey CJ. Angiogenesis in gastric ulcers: impaired in patients taking non-steroidal anti-inflammatory drugs. Gut. 1995; 37:191-194.

36. Kubota K, Kubota R, Yamada S. FDG accumulation in tumor tissue. J Nucl Med. 1993;34:419-421.

37. Qiu JM, Roberts SA, Potten CS. Cell migration in the small and large bowel shows a strong circadian rhythm. Epithelial Cell Biol. 1994;3:137-148.

38. Stappenbeck TS, Wong MH, Saam JR, Mysorekar IU, Gordon JI. Notes from some crypt watchers: regulation of renewal in the mouse intestinal epithelium. Curr Opin Cell Biol. 1998;10:702-709.

39. Brittan M, Wright NA. Stem cell in gastrointestinal structure and neoplastic development. Gut. 2004;53:899-910.

40. Schluter C, Duchrow M, Wohlenberg C, et al. The cell proliferation-associated antigen of antibody Ki-67: a very large, ubiquitous nuclear protein with numerous repeated elements, representing a new kind of cell cycle-maintaining proteins. J Cell Biol. 1993;123:513-522. 